HStud 24 (2010) 1, 135-166 DOI: 10.1556/HStud.24.2010.1.7

\title{
LOCAL SOVIETS AND COUNCILS IN THE EX-SOCIALIST EUROPEAN STATES WITH SPECIAL REGARD TO HUNGARY (1950-1990)
}

\author{
TAMÁS ANTAL \\ Szeged University, Szeged \\ Hungary
}

\begin{abstract}
The scholarly study and analysis of the Hungarian council system (1950-90) as a system of institutions and structure of public administration is a novel challenge rarely attempted to date in the field of the history of public administration. Although the period of 40 years under study is still something of a grey area for legal historians, there are already researchers and experts who venture into this territory. In addition to offering a historical overview, the present paper also analyses the life and operation of public administration in a specific historical and legal period from legal and administrative aspects. The council system, although undoubtedly still a subject of much debate and criticism, was definitely a possible form of public administration, and today constitutes an integral part of the history of the 20th century.
\end{abstract}

Keywords: constitutional history, legal history, history of public administration, Hungary 1949-1990, Central Europe, soviet law

\section{The Place of Soviets in the State of the Soviet Union}

When the tsarist police opened fire on the crowd demonstrating in Saint Petersburg on January 9th, 1905, nobody could have thought that not only would a new revolution soon start in Russia, but the beginnings of the soviets (советы), the new units of future regional public administration, would also begin to develop. Initially, they emerged without any intention to establish a state or to exercise power. At the time of the strikes held on May 1st, the workers set up strike committees organized by the Russian Social-Democratic Labour Party, or to be more precise inspired by its Bolshevik wing. The first of these was established in a textile industry plant in Ivanovo-Voznesensk. Similar workers' soviets were then organized one after the other in industrial centers. ${ }^{1}$

Meanwhile, the first State Duma (1905-06) did not regard the workers' councils as possible organs of public administration at all, and neither did the Russian Fundamental Law, promulgated on April 23, 1906, consider them as constitu- 
tional state-forming factors. ${ }^{2}$ It is important to remark that the first workers' soviets were originally organized in Russia not as units of public administration but as organizations inspired by revolutionary hopes, which also carried out de facto local tasks of public administration until the arrival of the tsarist forces. However, the memory of these early soviets was preserved among the workers: the financial and personal losses and deprivation suffered in World War I resulted in another strike in Saint Petersburg on February 23rd (March 8th by the Russian calendar), 1917 , on the International Women's Day, which once again led to a revolution, this time under organized control. ${ }^{3}$

The workers there established the soviets, the revolutionary institutions of power, early in the first days. The novelty of the soviets, in comparison with those of 1905, was that similar organizations were soon elected in most of the plants, and city soviets were also established to govern their activities. The (city) soviet of Saint Petersburg held its first session on the evening of February 27th. The Saint Petersburg soviet tried to control the city as a revolutionary governmental organ. ${ }^{4}$ Although the capital was practically under its control, on March 2nd power was handed over to the provisional bourgeois government led by A. F. Kerensky and G. Y. Lvov, in spite of the protests of the Bolsheviks. ${ }^{5}$

Nonetheless, the revolutionary events soon spread to the provinces, and workers' and peasants' soviets sprang up across the country. The situation of so-called dual power arose in this way: the dual state power of the bourgeois forces and the soviets, followed by the struggle between the two. Vladimir Ilyich Lenin, who was aware of the provisional nature of this historic situation, forecast the future in his April Theses: the new Russia would be "not a parliamentary republic but a republic of soviets of workers, agricultural laborers and peasants' deputies throughout the country, from top to bottom". In the spring of 1917 both the city soviets, which were elected on the basis of plant and professional principles, and the soviets of peasant deputies and their committees, which were based primarily on the regional principle, were established. Later regional and national centers were organized on the basis of these soviets. ${ }^{6}$ This was done in order to ensure something that was later laid down in the declaration issued by the Second All-Russian Congress, one day after the "socialist revolution", on October 26: "from now on all power is vested with the soviets". ?

It should also be mentioned that a decree was passed by the All-Russian Central Executive Committee on the right to recall the deputies, a characteristic of the soviet-type system of representation, as early as November $21 \mathrm{st}$ (December 4th by the Russian calendar). This right applied not only to the members of the Constituent Assembly, but also to organs of representation elected in cities and in zemstvos, the forms of local government that had existed in Russia since the state reforms under Alexander II. ${ }^{8}$ 
Finally, the people's commissar for interior affairs issued a general call for the transformation of local public administration on December 24th, 1917 (January 6th, 1918 by the Russian calendar). It confirmed that

\begin{abstract}
the organs of local power are the soviets, to which all the institutions of administration, economy, finance and culture-education shall subject themselves. The organization of central and local power in this manner is merely an organizational expression and reinforcement of the political fact that power in the country rests with the proletariat and semi-proletariat.
\end{abstract}

All the organs of local administration were to be replaced by regional, provincial and district soviets, as well as county and rural soviets in order to cover the entire territory of the country. It was thought that "the coherent, all-homogeneous organization - the Republic of the Soviets" could be accomplished in this manner. ${ }^{9}$

At the same time the council of people's commissars also provided for the legal status of soviets. They were declared to be entirely independent in local matters, but it was added that in the course of the fulfillment of their tasks they had to proceed pursuant to the resolutions of the superior soviet. A high-priority function was the execution of the legal acts of the central power (the council of people's commissars and the central executive committee) and the dissolution of organizations which were considered counter-revolutionary. As regards the internal structure of the soviets, the executive committee and the presidency were mentioned. ${ }^{10}$

The development of power exercised by the soviets could have been impeded by actually holding a Constituent Assembly. It was therefore dissolved on the second day of its convocation, on January 6 th, $1918 .{ }^{11}$ In any case, the traditional parliamentary form of government was declared to have outlived its purpose and to be absolutely incompatible with the aim of achieving socialism, as

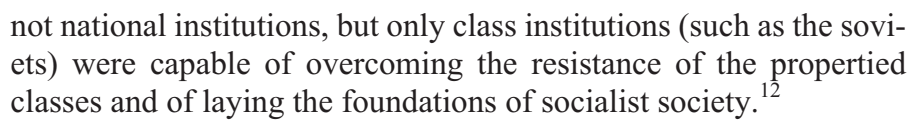

Finally, on July 10th, 1918 the first Soviet constitution described the public law organization of Soviet Russia as an already existing organization of regional and state organs of power. ${ }^{13}$ Its fundamental proposition was the establishment of a dictatorship of the urban and rural proletariat and the poorest peasantry for the purpose of creating a world without either a division into classes or a state of autocracy (Sections 9 and 10). In this system of public law the soviets were organized on a regional basis and operated in a hierarchical system. On a higher level congresses were recognized as organs of representation, which could be rural, 
county, provincial and regional. Their members were elected indirectly through the soviets of deputies. The latter category included the elected organs of cities and other settlements. In these the deputies' mandate lasted for three months.

In addition to the soviet bodies, executive committees also operated both on a higher, regional level (congress) and on a settlement level. Congresses were convoked by the executive committees at least twice a year for regions, every three months for provinces and counties, and once a month for rural districts. If the congresses were not in session, their scope of authority belonged to the executive committees. The system operated in a similar way in city and settlement soviets: executive organs were elected from among the members by the soviets of deputies in order to ensure continuous operation (Sections 53-60). In addition to soviets, special sections of administration had to be organized for the purpose of performing duties (Sections 60-63).

Theoretically, the right to vote was enjoyed by the following citizens of both sexes over the age of 18: all those who acquired the means of livelihood through labor that was seen as productive and useful to society and employed no help for the purpose of making profits; soldiers of the army and navy of the soviets; and citizens of the two preceding categories who in any degree lost their capacity to work. At the same time, the constitution expressly excluded several social strata from exercising the right to vote. These strata included big capitalists, big landowners and private merchants, employees and agents of the former tsarist police and gendarme corps, the members of the House of Romanov and clergy of all denominations (Sections 64-65).

This institutional system of the soviet-type public administration did not change essentially in the subsequent constitutions, either. It represented a special version of regional level state administration with mixed elements of the autonomy of self-government and normative central state control. After the establishment of the Soviet Union (December 30, 1922), the second Soviet constitution was promulgated on January 31,1924 . With regard to content, it only contained provisions concerning the operation of the federal state organs and the legal status of the member republics. ${ }^{14}$ The institutions of local and regional soviets were not mentioned.

The 1936 Constitution, ${ }^{15}$ which necessarily served as a model for people's democracies in Eastern-Central Europe after 1945, defined the public law framework of soviets as units of public administration in the chapter entitled "The local organs of state authority". According to this, the organs of state authority in territories, regions, autonomous regions, areas, districts, cities and rural localities were the soviets of working people's deputies. The deputies were elected by the working people for a term of two years. Their scope of authority was determined by the federal laws of the Soviet Union and by the member republics' own laws. 
The executive and operative organs of the soviets continued to be the executive committees, which consisted of a chairman, vice-chairmen, a secretary and members. The executive organs of the soviets were in double subordination. They were accountable both to the soviet which had elected them and to the executive committee of the respective superior soviet (Articles 94-101). In this way, in 1950 approximately 83,200 local soviets with almost 1.5 million local deputies operated in the Soviet Union. ${ }^{16}$

The last, 1977 Soviet federal constitution ${ }^{17}$ was considerably more developed and organized in structure than the earlier ones, and the legal status of the soviets was also regulated in more detail. In Chapter 12 this constitution also emphasized the principle that the soviets of people's deputies constituted a single system of bodies of state authority. This comprised all the soviets of people's deputies: the Supreme Soviet of the USSR, the Supreme Soviets of Union Republics, the Supreme Soviets of Autonomous Republics, the Soviets of People's Deputies of Territories and Regions, the Soviets of People's Deputies of Autonomous Regions and Autonomous Areas, and the Soviets of People's Deputies of districts, cities, city districts, settlements and villages. The deputies of the supreme soviets received their mandate for a term of five years, while local soviets were elected for two and a half years. The soviets of people's deputies set up standing commissions, executive-administrative bodies and people's control bodies (Articles 89-92). The executive bodies of soviets were still the executive committees, which had to report on their work at least once a year to the soviets that elected them, to the executive committee of the superior soviet, and to the citizens (Articles 149,150$){ }^{18}$

Elections were held pro forma on the basis of universal, equal, and direct suffrage by secret ballot, and the elected deputies could be instructed. These instructions had to be considered both by the soviets and by the people's deputies in them during their work, in accordance with the state interest of the time. Deputies, who did not justify the confidence of their constituents, could be recalled at any time by decision of a majority of the electors (Articles 95-107).

\section{Characteristics of Local Administration in European People's Democracies}

During the five years following World War II, state systems called people's democracy and regarded ideologically as "the revolutionary democratic dictatorship of the proletariat and the peasantry" were established in Central and Southern European states belonging to the Soviet sphere of interest. This led to the spread of public administration of the soviet and workers' council type, and the mutatis mutandis adoption of the soviet model. Thus on the Eastern side of the iron curtain 
council systems developed that bore many similarities, partly did away with the national self-governments of the bourgeois era, and operated not as representative bodies but with the participation of the deputies of mass organizations, which were like people's fronts in character. ${ }^{19}$

\begin{abstract}
Albania
The Constituent Assembly elections were held in Albania on December 2nd, 1945. The convention assembled on January 11th, 1946 and adopted a decision to transform the state into a people's republic. Soon after, on March 14th, the first Albanian constitution was adopted, while the second constitution was passed after several amendments on December 28th, $1976 .^{20}$

According to the 1976 Constitution, ${ }^{21}$ the units of Albanian regional public administration were people's councils (këshill popullor), which directed all social life in the political, economic, and social-cultural fields and the socialist judicial order and reconciled local interests with the general interests of the state. The people's councils were elected for a term of three years from among the candidates of the people's front (Democratic Front of Albania).

The people's council adopted the local financial plan and budget. From its members it elected the executive committee and the commissions of the council. It directed and controlled the activity of the people's councils at lower levels, and in order to achieve this it issued ordinances and decisions within its competences. A higher people's council could dissolve a lower people's council, order a new election, or abrogate its unlawful or irregular acts (Articles 92-95). The members of the people's councils enjoyed immunity within the territorial unit under the administration of the people's council.

The executive committee was the executive and administrative organ of the people's council. Between sessions of the people's council the executive committee exercised the rights and duties of the people's council, and it had to render account of its activity and report on the implementation of the decisions of the people's council. Albanian executive committees also operated in double subordination. They were dependent on the people's council on the one hand and on the next higher administrative executive organ on the other. The work of the people's council was assisted by specialized organs (Articles 92-100).
\end{abstract}

\title{
Bulgaria
}

The first elections after World War II were held in November, 1945, and the Great People's Assembly, which carried out constitutional tasks, was summoned. 
This activity was a relatively long process in Bulgaria, as the first constitution was adopted only on December 4th, 1947. The second one was promulgated much later, on May 18th, $1971 .^{22}$

Pursuant to the 1971 Constitution, ${ }^{23}$ the territory of the People's Republic of Bulgaria was divided into municipalities, capital districts and districts. People's councils (народни съвети) were the organs of state authority and people's self-government. In principle, their members were driven by the interests of the entire nation as such, by the interests of districts and municipalities as well as by the interests of the population in the constituency. The councils implemented the policy of the state in their own area of competence, in addition to which they made decisions on issues of local interest. In the course of their work, people's councils both passed and enforced resolutions. They controlled the development of the economic, social-health, public service, and cultural and educational conditions in their area. It was laid down as a principle that this activity would be performed with the consideration of all national and local interests and through the sectoral and regional planning of the complex development of the respective unit of public administration.

As part of their legislative activity, people's councils issued resolutions, decrees, regulations and directives. Sessions were held at least four times a year by district councils and at least six times a year by municipal and capital district councils. The Constitution also provided for the possibility to hold a referendum on issues of major significance.

The councils could elect and dissolve executive committees (изврини оgбори) as operative organs, in addition to which they set up standing and temporary committees as well as specialized administrative organs. The executive committees of higher councils had the right to suspend, or even to abrogate, the implementation of the unlawful or irregular acts and measures of lower-level councils. In any case, higher people's councils had the right to abrogate the legal acts of lower councils (Articles 109-124).

\section{Czechoslovakia}

In Czechoslovakia, the Constituent National Assembly was elected on May 26th, 1946. It finally adopted the new constitution on May 9th, 1948, at the same time repealing the 1920 constitution and generally all the rules of law which were in conflict with the new constitution and with the spirit of people's democracy. This fundamental source of law was later amended by several so-called constitutional laws until July 11 th, 1960, when a new constitution was adopted by the National Assembly. The latter was modified to a greater extent by Constitutional Act No. 143/1968, which transformed the socialist republic from a unitarian state into 
a federation. This was supplemented by Constitutional Act No 144/1968, which contained provisions on the status of ethnic minorities. These three rules of law together formed the constitution of Czechoslovakia. ${ }^{24}$

According to the 1960 Constitution, ${ }^{25}$ the organs of state authority and administration were regional, district, and community (city) national committees (národni výbory), the members (representatives) of which were elected by the people initially for four and later for five years. The representatives could be recalled and were at the same time accountable to their electors. The national committees were meant to fulfill their duties with the continuous and active participation of the workers. Representatives took an oath and pledged to comply with the people's will at the first session of the national committee.

Economic, cultural, health and social development was controlled, organized and ensured according to plan by the national committees in their respective area. Their primary duties included the satisfaction of the workers' material and cultural needs, the protection of socialist property, and the "socialist order" of society, as well as the implementation of the acts and the enforcement of the rights of socialist organizations. In the course of their work, they had to comply with the development plan of the national economy. They had to manage the material and financial means necessary for the realization of the planned tasks in a responsible manner.

The national committees observed the principle that the interests of the whole nation of the Socialist Republic of Czechoslovakia came before partial and local interests, and that through their overall activity they taught the citizens to fulfill their obligations towards society and the state in a conscious and voluntary way. For this purpose, the committees could pass decrees and set up a council, specialized committees and other organs. The council ( $\mathrm{rada}$ ) coordinated the work of the other bodies and institutions of the national committee. The members of the council were elected by the national committee from among its own members. The specialized committees were initiating, supervising and executive bodies, organized according to sectors of administration. Higher-level national committees exercised control over lower-level ones, while being obliged to respect their competences and responsibilities to the fullest extent. At the same time, higher-level committees had the right to abrogate the unlawful resolutions of their lower-level counterparts (Articles 86-96).

\section{The German Democratic Republic}

The problems faced by Germany after World War II, namely its division into zones of occupation and the suspension of its sovereignty, were settled in the spirit of the Cold War, and the country, or rather German countries, became an expres- 
sion of the global duality of democratic capitalist states and socialist people's democracies. Accordingly, the German Democratic Republic was founded on October 7th, 1949 out of the Soviet zone of occupation (i.e. the five eastern provinces: Saxony, Brandenburg, Mecklenburg, Saxony-Anhalt and Thuringia). The constitution proclaimed then declared the country to be the socialist state of workers and peasants. The second East-German constitution was passed on March 26th, 1968, and it was confirmed with a referendum on April 6th. ${ }^{26}$

In the GDR, pursuant to the 1968 Constitution, ${ }^{27}$ locally operating, elected bodies of state authority were called local people's representations (örtliche Volksvertretungen). These were established in administrative districts, rural counties, cities, city districts, communes and associations of communes. Their activity was primarily intended to augment and protect socialist property, continuously improve working and living conditions, promote the social and cultural lives of citizens and their communities, increase their knowledge of the socialist state and its laws, ensure law and order, strengthen socialist legitimacy, and protect civil rights.

Local people's representations made resolutions which had a binding force not only on their bodies and institutions but also on other people's representations, communes and citizens in their area. As an executive body, a council (Rat) and standing committees were elected, mostly from among the deputies, for performing the tasks. Thus in the system of the public administration of the GDR, contrary to the usual terminology the council meant not the elected representative body itself, but the executive committee. Consequently, it was responsible in its activities to the local people's representation and was subordinated to the higher council. The standing committees (as not only deputies could be members) made it possible for citizens to participate in the preparation and implementation of local resolutions. Local people's representations could form associations for the fulfillment of their duties (Articles 81-84).

\section{Poland}

The Polish elections for the Constituent National Assembly were held on January 19th, 1947. They resulted in the victory of the Democratic Bloc (the people's front). An act referred to as the "Small Constitution", or Mala Konstitucja, concerning the supreme organs of the republic was passed by the Sejm (the Polish Parliament) on February 19th, 1947. A separate act on the citizens' fundamental rights was passed on February 22nd. In 1950 an independent act was adopted on national councils, the organs of local power, as well as on the organization of the administration of justice. The uniform constitution was formulated only on July 
22nd, 1952. After several amendments, the quasi new text of the constitution in a uniform structure was promulgated on February 10th, $1976 .{ }^{28}$

In accordance with the 1976 Constitution, ${ }^{29}$ national councils (rady narodowe) were allegedly the working people's local organs of state authority in large villages, towns, districts of larger cities, and voivodeships. These expressed the workers' will and, in accordance with the intention of the legislators, promoted constructive initiatives in order to enhance the nation's strength and prosperity and develop its culture. They directed social, economic and cultural development in the areas proper to them and also exerted an influence on all public administrative and economic units. They saw to satisfying the population's needs, fought against all manifestations of absolutism and bureaucracy suffered by the citizenry, and organized the institutions of social control. The national councils had the right to determine the social-economic plan and budget of the voivodeship, town, district or large village on the basis of the proposals of the local organs of public administration.

The corporate activity of the national councils was exercised in sessions, which were organized and prepared for by the presidency. The voivods or town presidents or town leaders, district leaders and large village leaders were specifically one-person executive and operative bodies. At the same time, the voivods and the presidents of towns with voivodeship rank represented the government in their respective area of competence. They were all accountable to the national council operating on the given level. The latter were also assisted in their duties by various standing committees.

The national council had the right to abrogate a lower-level national council's legal act if it was deemed unlawful or incompatible with the political line of the state (Articles 43-54).

\section{Romania}

The first Romanian elections were held in 1948, following the proclamation of the people's republic. The Great National Assembly, which was convened at the time, adopted the first socialist constitution on April 13th, 1948. This was followed by the adoption of another constitution on September 24th, 1952, which was in effect until 1965. On August 21st, 1965 the third Romanian constitution was ratified, the most important amendment of which was the introduction of the institution of the President of the Republic in $1974 .{ }^{30}$

Pursuant to the last fundamental law of the Socialist Republic of Romania, ${ }^{31}$ people's councils (consilii populare) functioned as the local bodies of state authority charged with management of the local activities of public administration. 
Within this framework, they ensured economic, social, cultural, and city policing and community management development, as well as the protection of socialist property, the protection of the citizens' civil rights, and the maintenance of law and order. Their principal duties included accepting the local economic plan and budget, giving their exoneration to closed accounts, and electing and possibly recalling the executive committee. Given the hierarchical nature of the system, higher-level people's councils supervised the resolutions of the lower-level councils, and it was also the right of the people's councils to elect and recall judges, people's assessors, and county public prosecutors. The councils consisted of representatives (reprezentanți), who had a mandate for a term of five years in the counties and in Bucharest and a term of two and a half years in cities, communes, municipalities and the districts of Bucharest.

The executive committees and executive offices (comiteturi executive, birouri executive) were local operative bodies subordinated to the councils. They had a general scope of authority in the regional units of public administration where the people's council had been elected. The former operated in the counties, in Bucharest, in its districts and in the municipalities, while the latter worked in cities and communes. As part of their main tasks, they executed acts and law-decrees, the decrees of the Council of Ministers, and the other regulations of the higher bodies, as well as the resolutions of the people's council. They prepared the drafts of the local economic plans and budgets and also implemented them after their acceptance by the council. Moreover, they supervised the work of the executive committees or executive offices of the people's council subordinated to the people's council which had elected them.

These executive bodies were also entitled to make resolutions as part of their activities. They were responsible to the people's council, to the higher executive committee or office of the people's council, and ultimately to the Council of Ministers, both as a body and individually. They were assisted in their work by specialized organs of administration (Articles 86-100).

\section{Yugoslavia}

In Yugoslavia, where monarchy had been abolished de facto, the Provisional People's Assembly (Skupština), which also carried out constitutional tasks, assembled as early as August, 1945 and declared the country a democratic, federal state. The actual Constituent Assembly was opened on November 29th, 1945 and it de jure decided on the declaration of the people's republic. The first constitution was adopted on January 30th, 1946, the second on April 7th, 1963 and the third on February 21st, $1974 .^{32}$ 
The 1974 Constitution, ${ }^{33}$ which was unusually lengthy even by West European standards (consisting of 406 Articles), regarded regional administration as a form of self-management (samoupravljanje). This was due to the workers and citizens in settlements, in parts thereof or in several combined settlements. Self-management was interpreted as a collective right and obligation for the purpose of enforcing common interests and satisfying needs. Local communities had to be formed with local statutes and by-laws had to be adopted, which, among others, laid down the rights and obligations of administrative bodies and individual organs.

Communes (opštine) represented the basic self-managing social-political community. The communities carried out the tasks of exercising power and administering other social issues, unless otherwise provided for by the Constitution. Their tasks specifically included creating the conditions necessary for the productive lives of workers and citizens and the fulfillment of the material, social, cultural and other common needs in terms of self-management. They ensured the enforcement and protection of human and civil liberties, rights and obligations and the realization of the equality of nations and nationalities. The financial management of the communes was independent and there were possibilities for local referenda.

The principal organs of the self-managing activity of social-political communities were the representative bodies (predstavnička tela). These were characteristic of the basic self-managing communities organized on a personal, corporate, and regional basis, and therefore of local communes as well. These bodies were composed of delegates, who were elected by the workers for a term of four years by direct, secret ballot. Delegates could also be recalled. Delegates were nominated in the framework of a front-like organization called the Socialist Alliance of the Working People. The members of higher community representative bodies were decided upon by the councils of the representative bodies of communes on the basis of a ticket.

Various councils (veća) were formed within the representative bodies. They made resolutions independently, with equal rights or at the joint session of all the councils in matters belonging to their scope of authority. Such organs included the associated council of labor, the council of local communities, the council of communes, and the council of social policy. Thus essentially a specific, dual-structure system of local representation was realized in Yugoslavia, following the organization of the federative People's Assembly. The tasks of the executive organ were exercised by the executive council (izvršno veće), which was accountable to the representative body. The officers of the self-managing organs were also elected for a term of four years, and they could be re-elected once (Articles 114-151). 


\section{Fundamental Institutions of the Council System on the Example of Hungary}

After 1945, the soviet-type council system and the regional and national representation established on its basis constituted a new alternative to the institution of popular representation in the socialist countries. In both cases the corporate bodies (which were generally referred to as people's councils, or local people's representations in the GDR, national committees in Czechoslovakia and representative bodies in Yugoslavia) were comprised not of representatives who had been elected in accordance with the rules of plural party systems, but deputies who were elected through social-political mass organizations (people's fronts). The reason for this was simply that, with the exception of the GDR and Poland, there was no multiparty system in these countries, ${ }^{34}$ yet political systems of a state party character also tried to give the impression that the elections expressed the true will of the people, so candidates were nominated not by the party itself but formally by an organ which had the character of a people's front ${ }^{35}$ but which was essentially the equivalent of the party.

The legal status of the members of the councils elected in this way also differed substantially from that of the representatives of local governments in the bourgeois or contemporary sense. First of all, with the exception of Czechoslovakia and Romania, they were usually not called representatives but people's deputies. As a rule, the mandate of the deputy as a representative was not independent. In principle they could be recalled after their election in each country. This greatly limited their freedom to act. Furthermore, they were dependent on the political leadership. At the same time a hidden right of instruction was also provided for the electors through the obligation to report regularly (imperative-limitative mandate). This, in itself, would not have been a problem but for the fact that in reality the deputies' work was appraised by the party, which also exercised the right of recall. ${ }^{36}$

The operative and executive bodies of the councils were collegial bodies called executive committees. A different term (council) was used in the GDR and Czechoslovakia, but these should not be mistaken for representative bodies either. The only exception was Poland, where these duties were carried out by voivods, town presidents, district leaders and large village leaders as one-person bodies. In each country the committees were elected indirectly, that is by the council from among its own members, generally on the basis of the nomination of the Hazafias Népfront (Patriotic People's Front). As a rule, the executive committees were under double subordination. They were responsible both to the council which had elected them and to the executive committee of the superior council body. As a result, they did not always have autonomy to make decisions even in local matters. 
Their resolutions could be abrogated at any time by the regional bodies higher up in the hierarchy. ${ }^{37}$ Although most constitutions tried to mitigate this by stating that control could be exercised only in the case of a violation of the law, considerations of expediency were not uncommon. For instance, the Polish constitution laid down ex pressis verbis that the superior council could abrogate the resolution of a lower council body if it was deemed incompatible with the political line of the state, and the latter was determined by the state party at all times.

Thus it is obvious that no vertical division of the branches of power existed. Furthermore, the states of the people's democracies expressly denied their raison d'être. The system of state institutions was regarded as a unified and undivided system in which control was exercised by the working people and peasants through the state party, which was the sole oracle of social interests. At most, the differentiation of state tasks was recognized. ${ }^{38}$ It follows from the foregoing that even in the 1970s and 1980s councils were not real organs of self-government, in spite of the fact that the states tried to maintain this fiction by emphasizing the principle of democratic centralism. ${ }^{39}$ This did not mean that every decision was made centrally, on a national level (there were local, politically neutral matters), only that the possibility of such in the sense of public law was provided in each issue. This revealed the true totalitarian nature of the system.

As people's organs, the councils were part of this system. They adopted several functions and solutions from the despised, so-called bourgeois law, at the same time adding to it the ideology of misinterpreted Marxism, which never made mention of a de facto dictatorial and totalitarian state in its utopia. Councils were defined as the regional institutions of central, unified state power, which, in addition to managing local matters, invariably enforced the political aims and principles formulated by higher state and non-state organs. ${ }^{40}$ It is essential, as we stand at the close of the first decade of the 21 st century, to further our understanding of the system of councils and its complex operation. Political slogans notwithstanding, it constituted an unavoidable part of the 20th century history of Eastern-Central Europe immediately preceding the present constitutional systems. ${ }^{41}$

Of the countries under discussion here, Hungary was the only one to ratify only one constitution during the era of people's democracy, namely Act XX of 1949. The most extensive amendment was made by the National Assembly (Parliament) in 1972. Another interesting fact is that formally it is still in force, although the content was fundamentally changed in $1989 .{ }^{42}$

In terms of public administration, the territory of the People's Republic of Hungary was divided into counties (megyék), rural districts (járások), cities and communities, of which rural districts were abolished entirely in 1984. County, rural district, city, community and city district councils were delegated by the Constitution as the local organs of state authority. The members of the local councils were elected by the eligible voters in the given area for a different term in each cy- 
cle. The detailed rules pertaining to local councils (helyi tanácsok) were laid down by separate acts in Hungary, too. Among these, the first council act was passed by Parliament in 1950, the second in 1954 and the third in $1971 .^{43}$ The greatest novelty in the Act of 1971 was that the self-administrative function of the councils was emphasized, at least in principle.

\section{Scope of Authority and Competence of the Council}

The scope of authority of the councils widened and developed throughout the entire period under discussion, both in practice and on the level of normativity, and the Council Act of 1971 defined them in an extremely detailed manner. The rules of authority were usually not listed or repeated in the council's organizational rules. Instead, in these matters reference was usually made to superior rules of law.

Accordingly, at the beginning of the era, the responsibilities of the councils included in particular the management of local economic, social and cultural activities, the execution of acts and higher decrees, the direction and control over subordinate organs of state authority and state administration, the promotion of the protection of state order and public property, the protection of the workers' (the population's) rights, local economic plans and budgets and the supervision of their execution, the direction and control of the work of local economic companies, the support of the workers' (the population's) cooperatives, the election and possibly the recall of the members of the executive committee, the setting up of council commissions and the judgment of legal remedies filed against the resolutions of the executive committee (Article 27 of the Council Act of 1950).

The second council act, while maintaining these stipulations, supplemented the list. Thus several responsibilities were added to the scope of activity of the councils, including tasks relating to health care and social matters, the establishment of companies and organs to address local needs, the monitoring and appraisal of the operation of economic and other organs not subordinated to the councils, the election of the judges and lay assessors of courts, the protection of socialist rule of law and the consolidation of civil discipline, the protection of civil constitutional rights, and the enforcement of the rights of nationalities (Article 6 of the Council Act of 1954).

The third council act, while observing the new, local-government style objectives of the system, ${ }^{44}$ added further tasks to the authority of the councils, including tasks related to regional and settlement development, the provision and supervision of housing, and communal and commercial supply. The settlement arrangement plan was drawn up and supply institutions could be established, including budgetary firms. It was a significant step forward that the rule of law laid down the 
possibility, at least in theory, to manage the available financial means independently, within the framework of the accepted budget. The right to establish several institutions was extended by the right to organize institutions supplying the catchment area of the settlement. The town council was entitled to set up institutions of secondary education or institutions providing medical or social care (Articles 9-18 of the Council Act of 1971).

Lawmaking constituted an essential authorization awarded by all the acts to the councils. They were authorized to pass council decrees and resolutions and granted the right to review the resolutions of executive committees. For instance, during the 40 years of its existence, the council of Szeged passed 154 decrees. The most prolific period was the last decade of the communist era. ${ }^{45}$

The two manners of exercising authority, direct and transferable powers, were both included in all three acts. The latter manner merits particular attention from a legal perspective for the reason that the council, provided that a rule of law ${ }^{46}$ allowed it, could delegate the exercise of some of its powers to the executive committee, and in relation to this it was entitled to instruct the committee, or to abrogate or alter its resolutions. At the same time, certain powers could not be delegated. These included the establishment and the direction of the council organization, the drawing up of the development programs, the medium-term financial plan and budget, the defining of the main directions of the activity of the local council, the approval of the settlement arrangement plan, the execution of elections and appointments belonging to the council's scope of authority, the passing of council decrees and the right to elect lay assessors ${ }^{47}$ (Articles 4 and 5 of the Organizational and Operational Rules of 1984; hereinafter referred to as OOR). ${ }^{48}$

The regional competence of the council covered its own administrative area, or given villages (so-called peri-urban villages) in specifically defined cases.

\section{Legal Status of Council Members}

The council was a corporate body in character. Its members obtained their assignment as deputies (küldöttek) through elections. In terms of public law, deputies cannot be equated with representatives. The most important difference lay in the dependent, imperative nature of a deputy's mandate. A deputy could be instructed or even recalled by his/her electors. Thus in principle, after being elected, deputies legally depended on their electors, or in reality rather on the party. The rules of the elections were laid down in various acts or law-decrees, and also in the supplementary decrees of the Council of Ministers (government) and in the resolutions of the Presidential Council of the People's Republic, ${ }^{49}$ as a new rule of law was adopted by Parliament or by the Presidential Council prior to almost every council election. ${ }^{50}$ 
In accordance with these rules, elections for council members were held in $1950,1954,1958,1962,1967,1971,1973,1980$, and 1985. The mandate of the last elected council was prolonged by Act XXXIV of 1990 until September 23rd, 1990 , that is until the actual change-over to the system of local governments. In the course of the democratic transformation of 1989/90, councils were abolished and replaced with autonomous local governments by Act LXV of 1990. The introduction of the Act on Local Governments labeled the council system as a "dead end in history", notwithstanding the fact that this piece of legislation was drawn up on the basis of the draft of the fourth council act. While it has been and continues to be frequently criticized, it is still in effect. ${ }^{51}$

The council members' work was regarded by the second and the third council acts as an honorable public activity based on the electors' confidence. The council members' mandate, which could be won through nomination by the Patriotic People's Front ${ }^{52}$ and election by the citizens, was partly dependent in nature, as they could not be instructed in particular cases but could, in principle, be recalled by their electors. The number of the town council members changed regularly in each election. In Szeged, for example, their number was the highest between 1954 and 1958 (185 members) and the lowest between 1967 and 1971 (87 members).

The council members' rights included the following: the right to participate in lawmaking (council decrees, resolutions), the right to hold any council office and to participate in the work of the commissions, the right to represent the council, the right to put forward issues and proposals of public interest, the right to convene the meeting of the local electors and to give opinion on the drafts of the decisions of specialized organs of administration if they had a major impact on living conditions, rights and obligations of the citizens living in their constituency (Article 37 of the Council Act of 1971, Article 7 of Law-Decree 23 of 1983, Article 40 of OOR 1984).

At the same time, council members were required to represent the interests of the residents in their constituencies, take an active part in the work of the council, conduct themselves in a manner worthy of public activity and the electors' confidence, contribute to the strengthening of state and work discipline, protect the purity of public life and the property of the state, ensure the enforcement of the rights of the citizenry, observe the rules of legality and "socialist coexistence" in an exemplary manner, maintain direct and regular contact with the population, and enforce the assignments of the electors. Each council member had to report to his/her electors concerning the fulfillment of his/her obligations and the work performed at least once a year, and they cooperated with the residential and street committees $^{53}$ set up in their constituencies (Article 38 of the Council Act of 1971, Articles 40-41 of the OOR 1984). Another major entitlement of the council members was the right to submit interpellations at council meetings (Article 29 of OOR 1984). 
The council members' activity can be reconstructed on the basis of the minutes taken at council meetings. While in the 1950s the speeches made at the meetings almost exclusively approved, welcomed and supported everything, later, particularly from the time of the New Economic Mechanism onwards, ${ }^{54}$ an activity of greater merit unfolded. The members could voice their constructive opinions within reasonable limits. In Szeged, this culminated in the recall of the executive committee in 1988. Incidentally, the entire era was characterized by stereotyped speeches which were comprised of clichés and reminisced about the "liturgical" events of the past. Such notable events were particularly the arrival of the Soviet army in 1944/45, which was obligatorily referred to as liberation in Hungary, and the seizure of power by the Soviets in 1917 in Russia. Further frequently mentioned topics included the glorification of the Soviet Union, Stalin and subsequent leaders, references to the social class war, the fight against exploitation, criticism of the capitalist world economy, the personality cult, and the praise of the Hungarian party leaders, and the repeatedly emphasized development and superiority of socialism. Karl Marx's name was often cited in the service of these aims, notwithstanding the fact that the realities of socialist rule in Hungary had little to do with true Marxism. ${ }^{55}$

The more educated members of the councils and the council organization analyzed and assessed the activity of the organs of the Szeged town council more and more frequently in the last two decades leading up to 1989/90, since an effort was always made to include, in addition to the children of members of the working class, a few intellectuals or possibly scholars (scientists) among the council members.

\section{Corporate Activity of the Council}

The council held meetings as required, but not fewer than four times a year. For example, during the 40 years of its existence, the council of Szeged held 173 ordinary and 34 extraordinary meetings. ${ }^{56}$

The council meetings were convened by the executive committee on the basis of the pre-determined annual work schedule, but it was also possible to convene a meeting if proposed by one-fourth of the council members or if ordered by the Council of Ministers (government) or the executive committee of the superior county council. Each council meeting was held according to the agenda accepted by those present. The draft thereof was prepared by the executive committee, with the consideration of the proposals made by the city committee of the party and the county council of trade unions. The council members could also make proposals concerning the subject of the agenda (Article 17 of OOR 1984).

As a rule, the meetings were public, but a closed meeting could also be ordered, especially when cases of incompatibility were discussed. The meeting was 
opened by the council president (the chairman of the executive committee) and the meeting was usually presided over by him/her as well.

Customarily, first the reports on the implementation of previously passed resolutions were heard, put forward and presented by the council president (the chairman of the executive committee). Thereafter, the agenda was decided and each item was discussed. The rapporteur presented the written submission and the proposal for the resolution and then answered the questions, remarks and motions for amendment put to him/her during the debate. If no one else requested to speak, the chairman brought the question to a vote, which could be made with a 'yes', 'no' or abstention. In case of a tie vote, the chairman's vote was decisive. The voting was normally open; however, a secret ballot was held when the council president (the chairman of the executive committee), his/her deputy and the members of the executive committee were elected, or when cases concerning the incompatibility of council members were decided. Normally, a resolution could be passed with the majority vote of the council members present. In the case of a qualified vote, the legal norm was deemed to be adopted with the supporting votes of the majority of all the council members. Minutes were taken and the decrees and resolutions adopted were published first in extracts, then from 1971 in extenso in the official paper of the council (Articles 23-28, 30, 33 of OOR 1984).

The adoption of decrees was one of the major council rights. This could happen on the basis of a superior rule of law or a measure of a superior organ, or it could be initiated by the council itself with a view to settling local social conditions. When decrees affecting a wide range of the population were prepared, the draft was presented in consultation centers ${ }^{57}$ as well. In consequence of the hierarchical nature of the council system, ${ }^{58}$ the decree adopted had to be submitted to the executive committee of the superior council for legal supervision and approval (Article 36 of OOR 1984).

\section{Council Commissions}

In order to fulfill its tasks more efficiently, the council set up permanent and temporary commissions. The commissions were established and their members were elected by the statutory meeting of the council, but it could decide to set up further commissions or terminate or restructure the existing ones. As of 1971, it was compulsory to set up a rules commission and a finance commission, in addition to which the establishment of other commissions could also be provided for by the organizational rules (Article 65 of OOR 1984).

The tasks of these organs varied in character, but they included making proposals, offering opinions, and preparation, supervision and coordination. In the course of addressing these tasks, they participated in formulating and executing 
council plans and tasks, gave opinions concerning proposals of great importance, supervised the work and development of the different specialized organs and economic council companies, as well as the activity of non-council organs. They also organized the participation of the population in carrying out council tasks (Articles 56-59 of the Council Act of 1971).

The members of the commission could be nominated by the city committee of the Patriotic People's Front or by any council member, after which they and their chairmen were elected by the council itself. Each commission consisted of at least three members. The chairman and the majority of the members had to be council members. Other members could be nominated by local social and state organs or cooperatives, too. The commissions operated in a collegial form, and sub-commissions could also be set up to address certain matters (Articles 72-74 of OOR 1984).

The concrete tasks of the commissions were laid down in the organizational and operational rules. According to the OOR of 1984, the following commissions operated in Szeged: rules commission, auditing commission, city development and technical commission, production and supply commission, commission of culture and youth policy, commission of health and social policy and commission of law and administration (Article 70 of OOR 1984). In 1984 a peri-urban commission was set up by the Szeged council and by the councils of the neighboring settlements with a view to planned and efficient cooperation.

\section{The Executive Committee and its Functionaries}

The duties of the executive committee of the council (végrehajtó bizottság) as a general executive and operative organ ${ }^{59}$ included the implementation of rules of law, the harmonized enforcement of national and local public interests, the preparation of council meetings and the organization of the implementation of its decrees, the direction of specialized organs, the supervision of council companies, the direction of administrative council institutions and cooperation with non-council organs. This committee worked in double subordination. On the one hand, it was subordinated to the council which had elected it, and on the other hand to the superior executive committee. Its members were the chairman of the executive committee, who as of 1971 bore the title council president, his/her deputies (deputy council presidents), members elected by the council from among its own members, and the secretary of the committee. The members were elected after being nominated by the Patriotic People's Front (Article 17 of the Council Act of 1950, Article 31 of the Council Act of 1954, Article 41 of the Council Act of 1971). In Szeged the executive committee of the council was made up of some 11-15 members (the number varied in different cycles). 
The major duties of the executive committee were to prepare for the council meetings, control and organize the implementation of the council decrees and resolutions, and assist the work of the council members and its commissions. As part of its special powers, it coordinated and supervised the activity of the specialized organs and ensured professional and quick administration. It called the leaders of specialized organs to account. It could annul or modify any regulation issued by the specialized organs if it violated a rule of law or the perceived or alleged interests of the population. Finally, it made decisions in matters of appointment concerning these organs. Moreover, it also appointed the leaders of the council companies and institutions. It could submit a proposal to the superior executive committee (e.g., in the case of Szeged to the executive committee of Csongrád county) and to the superior specialized organs (Articles 41-43 of the Council Act of 1971). Its assignment lasted for the same duration of time as that of the council that had elected it.

The executive committee held its meetings as scheduled in the work plan, but at least once a month. The annual work plan prepared by the secretary contained the date of the meetings, the planned agenda and deadlines, the annual control plan and also individually determined action plans. The meetings were convened by the chairman of the committee (or council president as of 1971). However, it also had to be convened if proposed by the council itself, ordered by the executive committee of the superior council or the Council of Ministers, or initiated by one third of its members.

The meetings of the committee were not public. Its members, the local and superior committee of the party, the executive committee of the county council, the leader of the city public prosecutor's office and the police, the chairman of the local committee of the Patriotic People's Front and finally the presidents of the councils (chairmen of the executive committees) of the neighboring settlements had to be invited for the discussion of matters concerning them. In matters related to their duties, the chairmen of the council commissions and the leaders of the specialized organs were also entitled to be invited and attend (Articles 48-54 of OOR 1984).

The meeting of the executive committee was presided over by the chairman (chairman of the executive committee, council president), or if unable to attend, by his/her deputy. Generally, the president's account was discussed at the beginning of the meeting. It included the presidential decisions made between two meetings and the reasons underlying them, the report on the tasks performed and the manner of their execution (and in the case of any failure to complete a task, the reason for this failure and the person responsible), and other major measures and public events. The rules pertaining to council meetings were to be applied mutatis mutandis to the order of the meetings. The majority of the members had to be present for the meeting to have a quorum. The resolutions were passed with the major- 
ity decision of the members present. Minutes were taken, which had to be submitted to the executive committee of the superior council and the Council Office of the Council of Ministers ${ }^{60}$ (Articles 55-57 of OOR 1984).

The executive committee was led by the chairman of the executive committee (or council president), who at the same time was the highest ranking functionary in the entire council apparatus. The third council act abolished the term chairman of the executive committee and introduced the term council president. ${ }^{61}$ This expressed the legal status of the position more closely, and at the same time it also reflected the name adopted in public use at the time. A council president could only be a confidant of the party.

The chairman (president) was responsible for the preparation of the council meetings via the secretary of the executive committee. He/she presided over them, organized the implementation of the resolutions and decrees, and represented the council. He/she coordinated and assisted the work of council commissions, supervised the execution of the proposals made by the commissions, and informed them concerning major council tasks. The chairman (president) also convened and presided over the meetings of the executive committee, controlled and ensured the implementation of the resolutions, and gave an account of this to both the committee and the council. He/she also informed the latter of the annual activity of the executive committee. His/her tasks included the coordination of the work of council officials. In the course of this he/she could instruct and request reports from them. He/she supervised specialized organs, called their leaders to account, instructed them, and guided the personnel work (Article 59 of OOR 1984).

The chairman of the executive committee (council president) was elected on the nomination of the local committee of the Patriotic People's Front or any council member. Similarly, his/her recall could be initiated by the committee of the People's Front, the executive committee of the superior council, or the members of the local council. The council itself made the decision with the majority vote of the council members. Such an event only happened in exceptional cases, for instance in 1988 in Szeged, when the entire executive committee was recalled. ${ }^{62}$

There were two deputy chairmen of the executive committee (deputy council presidents), who were appointed by the council. Their main task was to assist the chairman (council president) in his/her work. Accordingly, they participated in directing the council organs. Their duties associated with the supervision of the specialized organs were distributed according to the sectors of administration. At the same time, they performed their own tasks. One of them dealt with matters of planned economy, finance and labor force management, and city development, the other with matters related to education, community culture, health, and sports activities (Articles 60-62 of OOR 1984).

The secretary of the executive committee also assisted the work of the council, the executive committee, and its chairman (council president). He/she had a con- 
siderable amount of administrative work to do in connection with the preparation of the meetings and the promulgation of the resolutions, and also in relation to the legal supervision of the official administration by specialized organs and council offices. He/she maintained contacts with several council and non-council organs (e.g., the public prosecutor's office, the court, and the police). If he/she noticed that any regulation made by the council or by its organs violated the law, he/she was obliged to report this (Articles 63-64 of OOR 1984).

The quality of the council apparatus has been the subject of considerable subsequent criticism, and duly so, as during the first decade significant problems arose in the work of the specialized organs of the council. This was rooted in the phenomenon known as cadre policy. Political (background) reliability was the only factor considered when selecting and replacing senior and middle executives. In consequence, not only were the members of the council bodies often entirely unqualified and unsuited to their tasks, but even posts as head of department were filled by people lacking the relevant skills. It took at least a decade to reconcile the requirements of professional competence and political reliability. ${ }^{63}$ In consequence, several operational anomalies arose in this period. The original profession and qualification of leading council executives was also typical. In Szeged, for instance, among the leading council executives one found a wood technician, a tailor's assistant, an onion gardener, a factory worker, an iron turner, a tiling assistant and an agricultural laborer.

In time the regime realized the resulting difficulties and employed considerably better educated officials. A significant outcome of this was that as of 1971 only a lawyer and as of 1982 only a specialist lawyer could hold the post of the secretary of the executive committee, even on village councils. It is worth emphasizing, however, that there were prominent intellectual experts in this period, too, whose devoted, self-sacrificing work made the administrative machinery work in spite of the many difficulties.

\section{Specialized Organs of the Executive Committee}

The tasks of specialized administration within the scope of authority of the council were performed by the specialized organs of the executive committee and by the council offices. The organizational rules of 1984 defined the following specialized organs in Szeged: department of health, department of construction and transport, department of administration, department of industry, department of commerce, department of food and agriculture, department of labor, department of culture, department of finance, department of personnel and further education, department of planning, supervisory department of physical education and sports, secretariat of economics, secretariat of organization and law. ${ }^{64}$ The internal struc- 
ture of each organ was determined by the executive committee. The council had and frequently exercised the right to change the structure (Article 77 of OOR 1984).

Their duties included, in particular, compiling the agendas of the corporate meetings in accordance with the regulations of the council or the executive committee or participating in making them, seeing to the implementation of the resolutions passed by the council or by the executive committee and the control thereof, and carrying out the administrative tasks related to the work of the respective council commission. Generally, council companies and other local institutions were also supervised and directed by these organs. The leader of each specialized organ rendered account of his/her activity to the council or to the executive committee at regular intervals. During their operation, these organs were supposed to adhere to the "socialist rule of law", arrange matters in an expedient and expert manner, refrain from bureaucracy, safeguard the rights of the citizenry, and promote the fulfillment of their obligations (Articles 79-83 of OOR 1984). The specialized organs of the council and the councils themselves had more wide-ranging duties than their predecessors in the former system of municipalities. $^{65}$ All this was a consequence of the centralization efforts of the state apparatus.

The county city office (megyei városi hivatal) worked as a special organ in cities of county rank as of 1979. As a rule, it administered official cases of first instance. The rules prescribed for specialized organs applied to its legal status. Its territorial jurisdiction extended to the entire city, and in certain cases to the neighboring settlements as well (Article 85 of OOR 1984). ${ }^{66}$

\section{A Brief Postscript}

The soviet-type council system has become part of legal history by now. It was not necessarily a better or worse form of public administration than the system of local governments currently in effect, only different in principle while similar in function. With all its merits and disadvantages, it was one possible model for the structure and institutional system of public administration. Precise knowledge and analysis of this system may be very informative when looking to the future, as well, not only in Hungary but also in Western Europe and the United States, as this type of the institutional system of public administration is still essentially unknown there. 


\section{Notes}

József Perényi and István Dolmányos (1994) A Szovjetunió története I. Oroszország története 1917-ig (The History of the Soviet Union. The History of Russia before 1917) (Budapest). 294-9.

2 Marc Szeftel (1976) The Russian Constitution of April 23rd, 1906. Political Institutions of the Duma Monarchy (Bruxelles), Szergej Juljevics Vitte (1964) Egy kegyvesztett visszaemlékezései (Memories of a Man out of Favour) (Budapest), 571-625, István Kovács (Editor) (1980) Az októberi dekrétumok és az elsö szovjet alkotmány (The Decrees of October and the First Soviet Constitution) (Budapest), 18-20, ШІ. В. Юшков (1950) История госуда рствва и права СССР. Часть первая (Москва), 584-631.

3 Miklós Kun (1988) 1917. Egy év krónikája (1917: Chronicle of One Year) (Budapest), 15-35, Юшков (1950) 644-53.

4 István Dolmányos (1989) A Szovjetunió története II. 1917-1966 (The History of the Soviet Union II. 1917-1966) (Budapest), 7-8.

5 Dolmányos (1989), 11-13

6 Kovács (1980), 21-50, Dolmányos (1989), 26-7.

7 'Munkás- és parasztküldöttek valamennyi kormányzósági és járási szovjetjének' (October 26, 1917) (For all the soviets of the worker and peasant deputies) in Kovács (1980), 87. For concrete example see: ‘Dekrétum a központi városi duma feloszlatásáról' (November 16, 1917) (Decree on the dissolution of the Central City Duma of Petrograd) in Kovács (1980), 137-8, see also $47-8$.

8 'Dekrétum a küldöttek visszahívásának jogáról' (November 21, 1917) (Decree on the right of recall of the deputies) in Kovács (1980), 140-1.

9 'A belügyi népbiztos felhívása a helyi önkormányzatok megszervezéséröl' (December 24, 1917) (Call of the people's commissar for interior affairs on the organisation of local governments) in Kovács (1980), 168-9.

10 'A belügyi népbiztos utasitása a szovjetek jogairól és kötelességeiről' (December 24, 1917) (Instruction of the people's commissar for interior affairs on the rights and duties of the soviets) in Kovács (1980), 173-4.

11 Kun (1988), 656-77.

12 'Dekrétum az alkotmányozó nemzetgyưlés feloszlatásáról' (January 6, 1918) (Decree on the dissolution of the Constituent Assembly) in Kovács (1980), 180-2.

13 'Az Oroszországi Szocialista Föderatív Köztársaság alkotmánya (alaptörvénye)' (Constitution of the Russian Socialist Federative Republic) in Kovács (1980), 217-46, József Ruszoly (2005) Európa alkotmánytörténete (The Constitution History of Europe) (Budapest), 526-53, Pál Horváth (1996) Bevezetés az egyetemes jogtörténet forrásaiba (Introduction to the Legal Sources of General Law History) (Budapest), 304-21, Dolmányos (1989), 87-90.

14 'A Szovjet Szocialista Köztársaságok Szövetségének alaptörvénye (alkotmánya). January 31, 1924' (Constitution of the Federation of Soviet Socialist Republics) in István Kovács (Editor) (1982), A Szovjetunió szövetségi alkotmányai (Federative Constitutions of the Soviet Union) (Budapest), 129-47.

15 'A Szovjet Szocialista Köztársaságok Szövetségének alkotmánya (alaptörvénye). December 5, 1936' (Constitution of the Federation of Soviet Socialist Republics) in Kovács (1982), 201-24, Pál Horváth (1987) A szocialista jogtípus fejlödéstörténete (The History of the Development of the Soviet-type Law) (Budapest), 69-73, Dolmányos (1989), 228-30.

16 Zoltán Szente (2006) Európai alkotmány- és parlamentarizmustörténet. 1945-2005 (The History of European Constitutions and Parliamentarianism: 1945-2005) (Budapest), 135. Concerning the soviets of the age, see: A. A. Aszkerov (1949) 'Az államhatalom helyi szovjet 
szervei' (The Local Soviet Organs of the State Authority), Állam és Igazgatás [Hereinafter ÁI] 1949/5-6, 303-11, 1949/7-8, 442-56, István Kovács (1950) 'A szovjetek a Szovjetunió politikai alapja' (The Soviets are the Political Basis of the Soviet Union), AI 1950/6-7: 436-50, I. Trajnyin (1950) 'A tanácsok - a szocialista forradalom politikai alapja' (Soviets The Political Basis of the Socialist Revolution), ÁI 1950/1, 8-21, 1950/2, 97-107, 1950/3, 149-54, 1950/4-5, 325-30, I. G. Marejeva (1951) 'A helyi szovjet ellenőrzése az igazgatási szervek felett' (The Supervision of the Administrative Organs by the Local Soviet), AI 1951/9-10, 547-56, A. V. Luzsin (1955) 'A dolgozók küldötteinek városi szovjetjei és a vb. tevékenységével kapcsolatos alapvető módszerek' (Fundamental Methods Connected with the Soviets of the Cities and the Executive Committees), ÁI 1955/11: 675-80, J. A. Tyihomirov (1960) ‘A helyi államhatalmi szervek további fejlődésének néhány kérdése a Szovjetunióban' (Some Questions of the Further Development of the Local Organs of State Authority in the Soviet Union), ÁI 1960/8, 581-94; 'Törvény a szovjet képviselők és tanácstagok jogállásáról' (Act on the Legal Status of the Representatives and Deputies of the Soviets), AI 1973/3: 259-66, 'Az OSzSzSzK törvénye a dolgozók küldötteinek városi, városi kerületi szovjetjeiről' (Act of the RSSFR on the Workers' Soviets of Cities and City Districts), ÁI 1973/6: 544-61, ‘Az OSzSzSzK törvénye a dolgozók küldötteinek járási szovjetjéről' (Act of the RSSFR on the Rural District Soviet of Workers' Deputies), ÁI 1973/6: 562-65.

A Szovjet Szocialista Köztársaságok Szövetségének alkotmánya. (1977. október 7.) (Constitution of the Federation of Soviet Socialist Republics) in Kovács (1982, 231-82), Horváth (1987, 202-3, 222-9).

18 Horváth (1987), 224-5, Árpád Árvay (1978) 'A helyi szovjetek tevékenységének pártirányítása' (The Control of the Party on the Activities of the Local Soviets), ÁI 1978/8-9, $738-46$.

19 General literature of the period: Ferenc Fejtő (1952) Histoire des démocraties populaires (Paris); augmented edition: Histoire des démocraties populaires. 1. L'ère de Staline (1945-1952); 2. Après Staline (1953-1963) (Paris, 1969; 1979; 1992; 1998; 2006); in Hebrew: Tel-Aviv, 1954; in Italian: Firenze, 1955; in Spanish: Barcelona, 1971; in English: New York-London, 1971; in German: Köln, 1973; in Japanese: Tokyo, 1978; in Hungarian: Budapest, 1991; William E. Butler (1983, 1988) Soviet Law (London), William E. Butler (1976) Russian and Soviet Law. An Annotated Catalogue of Reference Works, Legislation, Court Reports, Serials and Monographs on Russian and Soviet Law (Including International Law) (Zug), William E. Butler (1998) Collected Legislation of the Union of Soviet Socialist Republics and the Constituent Union Republics (New York); László Heka (2008) A szláv államok jogrendszerei (The Legal Systems of Slavic States) (Szeged).

20 István Kovács (Editor) (1985) Az európai népi demokráciák alkotmányai (Constitutions of the European People's Democracies) (Budapest), 65-6.

21 The text of the constitution of 1976 can be found in Kovács (1985), 67-83; see commentary in Horváth (1987), 299-300, 335, Barbara Jelavich (2000) A Balkán története. 20. század (The History of Balkan. The 20th Century) (Budapest), 290-2, 329-35, József Érchegyi (1951) 'Az Albán Népköztársaság államrendje’ (The State of the People's Republic of Albania), ÁI 1951/1-2, 100-8, Lajos Szamel (1951) ‘Az albán népi tanácsok szervezetének és múködésének új szabályozása' (The New Regulation of the System and Functioning of the Albanian People's Councils), ÁI 1951/3-4, 211-16.

22 Kovács (1985), 87-8.

23 The text of the constitution of 1971 can be found in Kovács (1985), 89-112; see commentary in Horváth (1987), 292-3, 321-6, Ferenc Toldi (Editor) (1977) Az európai népi demokratikus országok területi beosztása és tanácsi szervezete (The System of Councils and the Regional Divisions of the European People's Democratic Countries) (Budapest), 21-36, Emil 
Niederhauser (1959) Bulgária története (The History of Bulgaria) (Budapest), 209-24, Jelavich (2000), 276-90, 318-23, Dimitâr Koszev and Hriszto Hrisztov and Dimitâr Angelov (1971) Bulgária története (The History of Bulgaria) (Budapest), 219-71, Lajos Gyulai (1970) 'A helyi tanácsok reformja Bulgáriában' (The Reforms of the Local Councils in Bulgaria), AI 1970/5, 451-8, Mihajlov Dobromir (1979) ‘Közigazgatási reformok Bulgáriában’ (Administrative Reforms in Bulgaria), ÁI 1979/6, 510-18.

24 Kovács (1985), 115-17.

25 The text of the three constitutional acts can be found in Kovács (1985), 118-81; see commentary in Horváth (1987), 282-5, 309-14, Toldi (1977), 39-67, Szente (2006), 122-4, Rudolf Trella and Jaroslav Chavonec (1971) A Csehszlovák Szocialista Köztársaság új államjogi elrendezése (The New Constitutional System of the Socialist Republic of Czechoslovakia) (Bratislava), László Trócsányi (1955) 'Új jogszabály a csehszlovák nemzeti bizottságokról' (A New Law on the Czechoslovakian National Committees), ÁI 1955/1-2, 79-87, 'A nemzeti bizottságok albizottságai Csehszlovákiában' (The Sub-Committees of the National Committees in Czechoslovakia), ÁI 1962/4, 312-15, Gyula Fonyó (1966) 'A csehszlovák községi tanácsok munkájáról' (About the Work of the Czechoslovakian Local Councils), ÁI 1966/5, 435-50; 'Törvény a csehszlovák nemzeti bizottságokról' (Act on the Czechoslovakian National Committees), ÁI 1967/10, 942-58.

26 Kovács (1985), 343-6, László J. Nagy (2003) Az európai integráció politikatörténete (A Political History of the European Integration) (Szeged), 39-43, Norman M. Naimark (1995) The Russians in Germany. A History of the Soviet Zone of Occupation 1945-1949 (Cambridge).

27 The text of the constitution of 1968 can be found in Kovács (1985), 347-72; see commentary in Horváth (1987), 281-2, 304-9, Toldi (1977), 145-74, Szente (2006), 119-21, Horst Lipski (1972) ‘A leninizmus alkalmazásának tapasztalatai a Német Szocialista Egységpártban’ (The Experiences of the Adaptation of Leninism in the German Socialist United Party) in János Blaskovits (ed.) A népi Magyarország negyedszázada (The Quarter of a Century of the People's Hungary) (Budapest), 211-14, Heinrich August Winkler (2005) Németország története a modern korban, II (The History of Germany in the Modern Age, II) (Budapest), 113-441, Guidó Alt (1952) ‘Államigazgatási reform a Német Köztársaságban’ (Administrative Reform in the German Republic), ÁI 1952/10, 571-6, Guidó Alt (1953) 'Az NDK továbbfejleszti államigazgatását' (GDR Develops Its Administration), ÁI 1953/7-8, 411-16, Gábor Csollák and Ferenc Pusztai (1969) 'Tanácsi munka az NDK-ban' (Labour of Councils in the GDR), ÁI 1969/4, 332-43; ‘A Német Demokratikus Köztársaság törvénye a helyi tanácsokról' (Act of the German Democratic Republic on the Local Councils), ÁI 1973/12, 1110-41.

28 Kovács (1985, 317-20).

29 The text of the constitution of 1976 can be found in Kovács (1985), 321-40; see commentary in Horváth (1987), 285-91, 314-20, Szente (2006), 121-2, Toldi (1977), 103-41, Adam Lopatka (1976) 'A helyi hatalmi és igazgatási szervek reformjának befejezése a Lengyel Népköztársaságban' (Completing of the Reforms of the Organs of Local Power and Administration in Poland) Jogtudományi Közlöny 1976/10, 557-65, A Lengyel Népköztársaság 1983. évi törvénye a tanácsok és a területi önkormányzat rendszeréröl (1983. VII. 20.) (Act of 1983 of Poland on the System of Councils and Territorial Self-Government) (Budapest, 1984), Janusz Gołebiowski (1972) 'A szocializmus építésének általános törvényszerüségei és sajátos vonásai Lengyelországban' (General and Special Characteristics of the Development of Socialism in Poland) in János Blaskovits (ed.) A népi Magyarország negyedszázada (The Quarter of a Century of the People's Hungary) (Budapest), 167-72, Norbert Kolomejczyk (1972) 'A párt vezető szerepének egyes kérdései a szocializmus építésében Lengyelországban’ (Some Questions of the Leadership of the Party in the Development of the Socialism in Poland) in János Blaskovits (ed.) A népi Magyarország negyedszázada (1972, 173-8), Norman Davies 
(2006) Lengyelország története (The History of Poland) (Budapest), 837-928, János Horváth (1954) 'A lengyel népi tanácsok életéből' (From the Life of the Polish National Councils), ÁI 1954/6-7, 379-85, János Horváth (1955) 'A Lengyel Nemzeti Front és a lengyel népi tanácsok' (The Polish National Front and the Polish National Councils), ÁI 1955/1-2, 88-91, Ottó Farkas (1970) 'A lengyel népi tanácsok munkájáról' (About the Work of the Polish National Councils), ÁI 1970/1, 52-63; 'Törvény a lengyel nemzeti tanácsokról' (Act on the Polish National Councils), ÁI 1974/3, 250-71.

30 Kovács (1985), 375-6.

31 The text of the constitution of 1965 can be found in Kovács (1985), 377-402; see commentary in Horváth (1987), 293-5, 326-32, Toldi (1977), 177-94, Szente (2006), 128-9, Jelavich (2000), 323-9, Gheorghe Țuțui and Ionel Nicolae (1972) 'Átalakulások Románia társadalmi felépítésében' (Transformations in the Romanian Society) in: Blaskovits (ed.) A népi Magyarország negyedszázada 197-209, Catherine Durandin (1998) A román nép története (The History of the Romanian Nation) (Budapest), 321-449, 'A román néptanácsok életéből' (From the Life of the Romanian People's Councils), ÁI 1954/6-7, 388-92, 1954/10-11, 600-4, Fné [Mrs F.] (1955) 'A Nagy Nemzetgyülés és a népi tanácsok müködésének néhány időszerü kérdése a Román Népköztársaságban' (Some Questions of Functioning of the Great National Assembly and the People's Councils in Romania), ÁI 1955/5, 293-7, Fné [Mrs F.] (1956) 'Néptanácsi választások a Román Népköztársaságban' (Council Elections in the People’s Republic of Romania), ÁI 1956/4, 249-53, Gyula Fonyó (1966) 'A román községi néptanácsok müködéséről' (About the Functioning of the Romanian People's Councils of Communes), ÁI 1966/8, 749-61.

32 Kovács (1985), 53, 185-9.

33 The text of the constitution of 1974 can be found in Kovács (1985), 190-314; see commentary in Horváth (1987), 295-9, 332-40, Toldi (1977), 71-100, Szente (2006), 126-7, László Heka (2005) Szerbia állam- és jogtörténete (The Constitution and Law History of Serbia) (Szeged), 207-23, Ferenc Toldi (1967) 'A jugoszláv alkotmánytörténet áttekintése' (A Summary of the Yugoslavian Constitutional History) Állam-és Jogtudomány, Vol. 10, No. 1, 45-78, Jelavich (2000), 335-51, Ferenc Dallos (1956) ‘Jegyzetek Jugoszláviáról’ (Records on Yugoslavia), ÁI 1956/9, 556-65, Gyula Fonyó (1965) ‘Az igazgatás néhány új vonása Jugoszláviában’ (Some New Aspects of the Administration in Yugoslavia) ÁI 1965/3, 272-6, Albert Horváth (1968) 'A jugoszláv községi szkupstinák múködéséröl' (About the Functioning of the Yugoslavian Commune Skupstinas), ÁI 1968/9, 827-37.

34 Ottó Bihari (1980) 'Képviseleti rendszer' (System of Representation) in: Imre Szabó (Editor) Állam-és jogtudományi enciklopédia (Cyclopaedia of State and Law Sciences) (Budapest), Vol. II, 986.

35 The reason for this was that "it was a typical endeavour to exclude the working population from bodies of representation through legal regulations or by means of some other manipulations". Some authors, acting along the lines of the ideological guidelines of the era, especially in the 1950s, went as far as declaring universally that "bourgeois elections are the means of falsifying the true will of the people”. Bihari (1980), 984, István Kovács (1953) A burzsoá alkotmányosság válsága (The Crisis of Bourgeois Constitutionality) (Budapest), 180-203.

36 Ottó Bihari (1963) Az államhatalmi-képviseleti szervek elmélete (Theory of the Organs of State Authority and Representation) (Budapest), 137-54, Ottó Bihari (1965) 'A tanácsok államhatalmi jellege' (State-power Characteristics of the Councils), ÁI 1965/4, 358-70.

37 Bihari (1963), 228-31.

38 János Beér (1962) A helyi tanácsok kialakulása és fejlödése Magyarországon (1945-1960) (The Evolution and the Development of Local Councils in Hungary (1945-1960)) (Budapest) 5-9, János Beér, István Kovács and Lajos Szamel (1964) Magyar államjog (Hungarian State 
Law) (Budapest, 2nd ed.), 200-19, Lajos Szamel (1964) 'A Magyar Népköztársaság államszervezetének kialakulása és fejlödése' (The Evolution and Development of the Organism of the State of the People's Republic of Hungary) in Bálint Szabó (ed.) 20 év. Tanulmányok a szocialista Magyarország történetéböl (Budapest), 325-8, István Kovács (1962) A szocialista alkotmányfejlödés új elemei (Newer Elements of the Development of the Socialist Constitutions) (Budapest), 384-5, János Beér (1960) 'Az államhatalmi szervezet egysége a Magyar Népköztársaságban' (The Unity of the Organism of the State Authority in Hungary), ÁI 1960/4, 258-71, János Beér (1951) 'Helyi tanácsaink államhatalmi jellege' [State-power Characteristics of Our Local Councils), ÁI 1951/11-12, 593-606.

39 Sándor Berényi, János Martonyi and Lajos Szamel (1971) Magyar államigazgatási jog. Általános rész (Hungarian Administrative Law. General Studies) (Budapest), 138-53.

40 There are special studies on the interpretation of socialist ideology and the analysis of the soviet-type public administration from the inside in the legal journal published in Moscow in 1939, the first time under the title Советское Государство и Право. Sources in English include the books of William E. Butler (1992) Basic Legal Documents of the Soviet Legal System (New York, 3rd ed.), Russian Law. Historical and Political Perspectives (Leyden, 1977), and William E. Butler, Peter B. Maggs and John N. Hazard (1977) The Soviet Legal System: Fundamental Principles and Historical Commentary (New York).

41 The main constitutional reforms of the countries mentioned were adopted in 1989 and 1990. In most of them the introduction of democratic legal institutions took place peacefully, with the exception of the revolution in Romania (Christmas of 1989) and the civil war in the former Yugoslavia (1991-95, 1996-99). The German Democratic Republic ceased to exist with the reunion of the German states in 1990. Czechoslovakia split into two sovereign states on the first day of 1993.

42 Lajos Izsák (2002) A Political History of Hungary 1944-1990 (Budapest), István Kukorelli (2000) 'A Historical Outline of Hungarian Constitution and State: 1949-1989' in Gábor Máthé (ed.) The Hungarian State 1000-2000. Thousand Years in Europe (Budapest), 440-53.

43 Act I of 1950, Act X of 1954 and Act I of 1971 on the Local Councils.

44 The Council Act of 1971 emphasized the self-governing nature of local councils, which was also indicated by terminating the legal subordination and superordination between council bodies. However, this applied neither to the executive committees nor to the party organs, which meant that no self-government in the true sense of the word could be realized. County council organs could instruct the city and village council organs in individual cases.

45 György Szilágyi (2003) Ahogy a Torony alatt láttam és megéltem... Szemelvények Szeged XX. századi közigazgatás-történetéböl (As I Experienced under the 'Tower': Extracts from the History of the Public Administration of Szeged in the 20th Century) (Szeged), 118-72, Tamás Antal (2009) A tanácsrendszer és jogintézményei Szegeden (1950-1990) (The System of Councils and Its Legal Institutions in Szeged (1950-1990)) (Szeged), 153-79.

46 In the period under study, the following qualified as rules of law in Hungary: acts, law-decrees, decrees and resolutions of the Council of Ministers/government and council decrees. Of these, law-decrees may need some explanation. As between 1949 and 1988 Parliament held sessions only for a few days of the year, it could not pass any legislation of merit. The Presidential Council of the People's Republic was authorized by the constitution to substitute law-decrees for statutory norms. In the hierarchy of legal sources these were on the same level as acts until 1987, thus they could even amend them. Although the Presidential Council had to present these legal sources to Parliament subsequently and in principle Parliament had the right to raise objections, it never did so. See Article 6 of Act XI of 1987 on Legislation.

47 Lay assessors embodied lay and collective judgement in Hungarian courts. Generally, judicial councils consisted of one professional judge and two lay assessors. Judges had the decisive 
role in the process of making decisions. The system of assessors is not of Hungarian origin, it developed from the German Schöffengericht. F. Battenberg (1990) 'Schöffen, Schöffengericht' in: Adalbert Erler and Ekkehard Kaufman (Hrsg.) Handwörtherbuch zur Deutschen Rechtsgeschichte. IV. (Berlin), 1463-9, Markus Dirk Dubber (1995) 'The German Jury and the Metaphysical Volk: From Romantic Idealism to Nazi Ideology', The American Journal of Comparative Law Vol. 43, No. 2, 230-1.

48 Decree 1/1984 of the Council of Szeged, City of County Rank, on the Organizational and Operational Rules of the Council. In: Szeged Megyei Városi Tanács Közlönye 31 March 1984. No. 3, 3-40.

49 The Presidential Council of the People's Republic was a collegial head of state in Hungary between 1949 and 1989. This meant that the rights of head of state were exercised not by one person (e.g., President of the Republic) but by this body, which consisted of 21 members: a chairman, two deputy chairmen, a secretary and 17 members who were elected by Parliament from among its own delegates. Consequently, the members were necessarily members of Parliament as well, with the restriction that a member of the Council of Ministers could not be a member of the Presidential Council at the same time. Essentially, it also functioned as a substitute for Parliament. As such, it was entitled to issue law-decrees on its own, with the requirement of subsequent submission to Parliament, and it could also pass other decrees and resolutions. Antal Ádám (1959) A Népköztársaság Elnöki Tanácsa (The Presidential Council of the People's Republic) (Budapest), Antal (2009), 130-1.

50 Law-decree 31 of 1950, Act IX of 1954, Law-decree 22 of 1954, Act III of 1958, Act V of 1962, Act III of 1966, Act I of 1970, Act VI of 1976, Act III of 1983 and Act XI of 1989. For a detailed description of these elections see Szilágyi (2003), 58-75, Kukorelli (2000), 449-50.

51 Act LXV of 1990 on Local Governments and Act LXIV of 1990 on Election of the Members of Local Governments and the Local Mayors.

52 The Patriotic People's Front (and its predecessor, the Hungarian Independent People's Front) functioned as a sort of socialized counterpart of the state party (the Hungarian Workers' Party, then as of 1957 the Hungarian Socialist Labour Party) as of 1954 to make it appear as if elections were not entirely one-party in Hungary. Officially, it constituted the "mass foundation" of the councils. In reality, although it served as an umbrella organization for several social organizations, it was a political organization controlled by the party, which, among exercising other powers, nominated the members of Parliament and the council members. No opposing candidate could be nominated until 1971, and votes against the candidate of the People's Front were usually regarded as invalid. For more details see: A magyar Népfront története (The History of the Hungarian People's Front), Vol. 2. (Budapest, 1977), 178-488.

53 Street committees were officially the population's unprompted social organs of representation. Their activity, as was the case with other, similarly mass-social institutions of the era, was of a nature of mass movement and organization as they performed tasks of mobilization, information and opinion survey in the framework of the People's Front. At the same time they represented the interests of the citizenry as well as organized social labor and saw to the adherence to the rules of the blocks of flats. In addition, they also made the citizens' direct surveillance possible for the secret services. Antal (2009), 163-9, Béla Révész (2007) ‘A titkosszolgálatok a politikában és a politológiában' (Secret Services in Politics and Politology), Acta Jur. et Pol. Szeged. Vol. 70, No. 13. (Szeged).

54 The New Economic Mechanism between 1968 and 1974 aimed to realize the major transformation of the Hungarian economy under directive plan instructions and to establish "simulated market conditions". It had significant results. Economic performance increased drastically, as did the standard of living and the pace of urbanization. The economy of Hungary became the most prominent among the socialist countries in Central Europe. This period was nicknamed 
“goulash communism”. T. Iván Berend and György Ránki (1972) A magyar gazdaság száz éve (100 Years of the Hungarian Economy) (Budapest), 227-304, T. Iván Berend (1988) A magyar gazdasági reform útján (The Way of the Hungarian Economic Reform) (Budapest), 177-366, T. Iván Berend (1979) A szocialista gazdaság fejlödése Magyarországon (Development of Socialist Economy in Hungary) 1945-1975. (Budapest), 142-56.

55 See arguably his most important work: Karl Marx (1906) Capital. A Critique of Political Economy. The Process of Capitalist Production. Translation from the German by Samuel Moore, Edward Aveling; edited by Frederick Engels; rev., amplified according to the 4th German edition by Ernest Untermann (New York).

56 For the statistics thereof see: Szilágyi (2003), 114.

57 Consultation centers functioned as a form of manifestation of "socialist democracy" in the period of the third council act. These were established in the wake of the recognition of the social-political importance of work in one's dwelling area. As de-concentration centers in given areas of the city, they served as places for consultation for the district party leadership and People's Front committee, the city council members, resident and street committees and inhabitants interested in public matters. In reality their work had little importance.

58 The hierarchy of the council system was based on the principle of "democratic centralism". This meant that each council and council organ could be instructed by the superior organs of state authority or state administration, which in turn were controlled by the analogous party organs. Therefore, however, as much as the third council act attempted to ease this obvious system of dependence, real local governments did not exist at that time, either. The possibility to instruct executive committees existed throughout the entire period, which is why it was possible, if deemed necessary, to control local decisions by the metropolitan government and party organs. This was also the reason for the administrative patronage: the authority of the superior executive committees to approve decrees and resolutions. László Kiss (2000) 'A tanácsi szervek politikai (párt) irányításának néhány kérdése Magyarországon’ (Some Issues of the Political (Party) Control of Council Organs in Hungary) in: József Petrétei (ed.) Emlékkönyv Ádám Antal egyetemi tanár születésének 70. évfordulójára (Budapest-Pécs), 134-6, BerényiMartonyi-Szamel (1971), 428-32.

59 János Sári (1979) A tanács végrehajtó bizottsága és tisztségviselői (The Executive Committee of the Council and Its Functionaries) (Budapest), Pál Fürcht (1974) 'A tanács és a végrehajtó bizottság kapcsolata' (The Connection of the Council and the Executive Committee), ÁI 1974/12, 1125-34.

60 The technical supervision of the council organization was carried out in the government by the Department of Government Secretariat for Local Councils, and as of 1971 by the Council Office of the Council of Ministers as a special organizational unit in the government. János Beér (1962) A helyi tanácsok kialakulása és fejlödése Magyarországon (1945-1960) (The Evolution and the Development of Local Councils in Hungary (1945-1960)) (Budapest), 417, BeérKovács-Szamel (1964), 325.

61 See Article 51 of Act I of 1971.

62 László Blazovich (ed.) Csongrád megye tanácsainak tisztségviselöi (Functionaries of the Councils of Csongrád County) (Szeged, 2007), 34. For their and many other people's biographies see: György Antalffy (Chief Editor) A munkásmozgalom Csongrád megyei harcosainak életrajzi lexikona (Biographical Encyclopaedia of the Fighters of the Working-Class Movement in Csongrád County) (Szeged, 1987).

63 Ferenc Dallos (1950) 'Helyes munkaszervezéssel javítsuk végrehajtó bizottságaink munkáját' (Let us Improve the Work of Executive Committees with the Proper Organization of Work), ÁI 1950/8-9, 507-15, Gyula Bodovszky (1952) 'Emeljük a végrehajtó bizottságok munkájának színvonalát' (Let us Raise the Level of Work of Executive Committees), ÁI 1952/7, 
350-6, Imre Zagyva (1960) ‘A tanácsi végrehajtó bizottsági vezetők képzésének néhány problémája' (Some Problems of the Training of the Leaders of the Executive Committees of Councils), ÁI 1960/11, 853-7, Ottó Farkas (1963) 'A végrehajtó bizottságok vezetői képzésének néhány kérdése' (Some Issues of the Training of the Leaders of Executive Committees), ÁI 1963/12, 908-18, József Károlyi (1967) 'A végrehajtó bizottságok vezetőinek szakmai és politikai továbbképzése' (Professional and Political Further Education of the Leaders of the Executive Committees), ÁI 1967/7, 628-35, Berényi-Martonyi-Szamel (1971), 549-66.

64 Blazovich (2007), 35-9.

65 Municipal public administration existed between 1872 and 1950 in Hungary. Essentially, it was of a local governmental nature, yet it cannot be identified with local governments in the classical sense on account of the composition of the municipal committee on the one hand, and the considerably milder control exercised by the government on the other. József Ruszoly (2004) Szeged szabad királyi város törvényhatósága (1872-1944) (The Municipality of the Free Royal City of Szeged) (Szeged).

66 Antal (2009), 327-40. 